\title{
ULTRASONOGRAPHIC INDICES OF SKIN CHANGES IN CHILDREN WITH HELICOBACTER PYLORI-ASSOCIATED GASTRODUODENITIS COMBINED WITH FOOD ALLERGY
}

\author{
Tamila V. SOROKMAN ${ }^{1 凶}$, Snizhana V. SOKOLNYK ${ }^{1}$, Iruna Ya. LOZYUK ${ }^{1}$, \\ Sergii 0. SOKOLNYK ${ }^{2}$, Pavlo M. MOLDOVAN ${ }^{1}$, Tamara H. KOPCHUK ${ }^{3}$, Karolina I. YAKOVETS ${ }^{4}$ \\ ${ }^{1}$ Department of Pediatrics and Medical Genetics of Bukovinian State Medical University, Chernivtsi, \\ Ukraine \\ ${ }^{2}$ Department of Pediatric Surgery and Otolaryngology of Bukovinian State Medical University, Chernivtsi, \\ Ukraine \\ ${ }^{3}$ Department of Pharmacology of Bukovinian State Medical University, Chernivtsi, Ukraine \\ ${ }^{4}$ Department of Children Surgery and Otolaryngology of Bukovinian State Medical University, Chernivtsi, \\ Ukraine
}

\section{Abstract}

Introduction. To date, there are no early diagnostic criteria for skin changes in children with combined pathology of the gastrointestinal tract and food sensitization.

Objective. To determine the ultrasound parameters of skin changes in children with Helicobacter pylori-associated chronic gastroduodenitis (CGD) combined with food allergy (FA).

Methods. 168 children with $\mathrm{H}$. pylori-associated CGD in combination with FA, aged between 7-15 years, were involved in a study of ultrasound parameters of skin change. Skin ultrasound was performed by ultrasound scanners with linear sensors, with variable frequency, 3.5-12.0 MHz. Average values are given in the form $(M \pm m)$, where $M$ is the mean value of the index, $\mathrm{m}$ is the standard error of the mean, $\mathrm{n}-$ the volume of the analyzed group.

\section{Résumé}

Criteres ultrasonographiques des modifications de la peau chez les enfants avec gastroduodenite a Helicobacter pylori associée a une allergie alimentaire

Introduction. À l'heure actuelle, il n'y a pas de critères de diagnostic précoce de la peau chez les enfants atteints d'une pathologie combinée du tractus gastro-intestinal et de sensibilisation alimentaire.

Objectif: déterminer les paramètres ultrasonographiques des changements de la peau chez les enfants avec GDC associée à $H$. pylori en combinaison avec des AA.

Méthodes. 168 enfants avec GDC à H. pylori associée à $\mathrm{AA}$, àgés de 7 ans à 15 ans ont été introduits dans une étude des paramètres ultrasonographiques des modifications de la peau. Le scanning à ultrasons 
Results. In the acute period, children with $\mathrm{H}$. pylori-associated CGD combined with FA were characterized by pronounced thickening of the skin (epidermis, derma), unclearness of the layers of the skin, increased echogenicity of the epidermis, diffuse reduction of echogenicity of the dermis and heterogeneity of its structure, characteristic hypoechoic strip between the epidermis and dermis, stronger intra-dermal and subcutaneous arterial and venous circulation. In the subacute period, the ultrasonographic skin changes in the affected children faded and were less pronounced in remission.

Conclusions. The peculiarity of the ultrasound structure of the skin in children with $\mathrm{H}$-pylori-associated CGD in combination with FA is a pronounced thickening of all its layers, the presence of a hypoechoic strip in the superficial layer of the dermis and the strengthening of intradermal and subcutaneous arterial and venous blood flow.

Keywords: H. pylori-associated chronic gastroduodenitis, food allergy, ultrasound skin markers.

Abbreviations: CGD - chronic gastroduodenitis, FA - food allergy, SCORAD - Scoring atopic dermatitis.

\section{INTRODUCTION}

Deterioration of the environment, pollution of the atmosphere, new food and preservatives, lead to a general allergization in the population and the emergence of various diseases with an allergic component ${ }^{1}$. The combination of pathologies of the gastrointestinal tract, in particular chronic gastroduodenitis (CGD), with food allergy (FA) is of particular interest $^{2,3}$. In the structure of diseases of the gastrointestinal tract in children CGD takes up 45-55\% $\%^{4-9}$. The incidence of CGD associated with Helicobacter pylori (H. pylori) infection varies according to the age of the child, being $20 \%$ in children aged $4-9$ years, $40 \%$ in children aged between $10-14$ years, and $52-70 \%$ in children over 15 years and adults ${ }^{10-13}$. The prevalence of FA among children ranges from 12.0 to $37.0 \%$, which is significantly higher than in adults ${ }^{14-17}$. Most researchers emphasize the only mechanism of the occurrence of this pathology - the immunoallergic one $e^{18-20}$. a été réalisé avec des capteurs linéaires à fréquence variable 3,5-12,0 $\mathrm{MHz}$. Les valeurs moyennes sont présentées sous la forme de $(\mathrm{M} \pm \mathrm{m})$, où $\mathrm{M}$ - le taux moyen, $\mathrm{m}$ - erreur type de la moyenne; $\mathrm{n}$ - la quantité d'un groupe d'essai.

Résultats. Dans la phase aiguë, les enfants atteints de GDC associée à $\mathrm{H}$. pylori associé à AA ont été caractérisés par un épaississement notable de la peau (épiderme, derme), violation des couches de clarté de la peau, l'augmentation de l'échogénicité de l'épiderme, une diminution diffuse de l'échogénicité et de l'hétérogénéité de sa structure, des bandes caractéristiques d'aspect hypoéchogène entre l'épiderme et le derme,une circulation veineuse et artérielle intra-cutanée et sous-cutanée plus forte. Dans la période subaiguë les changements ultrasonographiques de la peau chez les enfants affectés se sont effacés et ont été moins prononcées en rémission.

Conclusion. La caractéristique de la structure de la peau par ultrasons chez les enfants atteints de GDC associée à $\mathrm{H}$-pylori conjointement avec AA est l'épaississement marqué de toutes ses couches, la présence de bandes hypoéchogènes dans la couche superficielle du derme et l'amélioration de la circulation veineuse et artérielle intradermique et sous-cutanée .

Mots-clés: gastroduodénite chronique associé à $\mathrm{H}$-pylori , allergie alimentaire, marqueurs de la peau à ultrasons.

Abréviations: GDC - gastroduodénite chronique, AA - allergies alimentaires.

Morphologically, such patients have allergic reactions in the mucous membranes and skin ${ }^{21}$. It is believed that $\mathrm{H}$. pylori infection not only causes classical antral gastritis, but also plays the role of a trigger mechanism of immune responses in the mucous membrane of the stomach and skin. On the other hand, it is known that FA develops because the child's body has a physiological, morphological, enzymatic and immunological imperfection of the protective barrier of the small intestine, that is easily damaged and makes it possible for the immunogenic components of food to penetrate it, manifesting clinically by inflammation of the skin and mucous membrane. However, there are no early diagnostic criteria for skin changes in children with combined pathology of the gastrointestinal tract and food sensitization ${ }^{22}$. It is not possible to avoid subjectivity in the assessment of skin manifestations and response to therapy. In this regard, the development of objective diagnostic methods for the timely detection of the nature of skin lesions, like ultrasonography of the skin, may 
be necessary ${ }^{23}$. As a noninvasive and independent of subjective judgment method, ultrasonography should be included in overall evaluation of food allergy disease severity, together with common scores or scales, especially in the era of evidence-based medicine ${ }^{24-29}$.

The objective of The STUDY was to determine the ultrasound parameters of skin changes in children with $\mathrm{H}$. pylori-associated chronic gastroduodenitis combined with food allergy.

\section{MATERIAL AND METHODS}

168 children with $\mathrm{H}$. pylori-associated CGD, in combination with FA, aged between $7-15$ years, were involved in a study of ultrasound parameters of skin change. The children were treated in Chernivtsi Regional Pediatric Clinical Hospital, Ukraine, between 2012 - 2017. The average age of children was $11.1 \pm 0.7$ years. 108 boys and 60 girls were included in the study. The inclusion criteria were: age of patients from 7 to 15 years, residents in Chernivtsi region, Ukraine, a confirmed diagnosis of $\mathrm{H}$. pylori-associated CGD in conjunction with FA. The exclusion criteria were: age of children under 1 year, children with infectious-inflammatory, parasitic or autoimmune skin diseases, genodermatoses, contact dermatitis, the presence of congenital immunodeficiency, skin manifestations of systemic diseases, metabolic disorders and neoplastic processes.

The control group consisted of 30 practically healthy children. The criteria for inclusion of children in the control group were: the absence of an allergic disease, a negative hereditary history of atopy, absence of chronic diseases, including the gastrointestinal or infectious diseases within 3 months before the examination, normal complete blood count and urine exam.

The diagnosis of H. pylori-associated CGD in children was made in accordance with the unified protocol „Pediatric Gastroenterology ${ }^{\text {"30 }}$. The gastroduodenal mucosal infection with Helicobacter pylori (H. pylori) has been confirmed by two methods (morphological and enzyme immunoassay method). Children have been divided into groups, according to the period of clinical course of FA (acute, subacute, remission).

Skin ultrasound was performed by ultrasound scanners Siemens Sonoline Adara (Germany), GE Logiq 100 Pro (Germany) and Medison SonoAce 8000 Prime (Korea), with linear sensors with variable frequency, 3.5-12.0 MHz. The study was conducted in the $\mathrm{M}$ - and B-mode, as well as with the use of Doppler techniques. Ultrasonography allows an objective study of the skin structure qualitatively - with the help of a visual assessment of the ultrasonographic picture - and quantitatively, the thickness of each layer of the skin and the level of its echogenicity/ acoustic density of the tissue. The dimensions of the observed structures with ultrasound of the skin were measured in micrometers $\left(1 \mathrm{Mm}=1^{\prime} 10^{-6} \mathrm{~m}\right)$ or millimeters $\left(1 \mathrm{~mm}=11^{\prime} 10^{-3} \mathrm{~m}\right)$. Echogenicity $/$ acoustic density is measured in standard units from 0 to 255 , the color scale included 256 different colors or 256 shades of gray. The depth of penetration is inversely proportional to the frequency and varied from 1.5 to $15 \mathrm{~mm}$. Epidermis, dermis and subcutaneous adipose tissue were visualized. The differentiation of the layers of the skin (epidermis and dermis) was assessed, the characteristics of their boundaries, thickness, echostructure, echogenicity, the presence of intracranial and subcutaneous arterial and venous blood flow, as well as the state of regional lymph nodes were determined. In order to prevent excessive pressure on the skin, the sensor used a helium "pillow“ as an acoustic window. Ultrasound of the skin began in the traditional $\mathrm{M}$ - and $\mathrm{B}$-mode, by transverse and longitudinal scanning of the skin areas of interest. Color and energy Doppler scanning was used to study the skin's vascularization. In Doppler evaluation, the vascularization and the condition of the blood circulation in the skin were examined. Scanograms of the skin structure were obtained, according to which the thickness of the skin and individual layers of the skin (epidermis, dermis, subcutaneous fat layer, as well as their acoustic density - echogenicity) were measured. All structural changes in the skin revealed in the test area, of diffuse and/ or focal nature, were described in accordance with the traditional ultrasound protocol. The evaluation of the echographic structure of the skin, the state of intracranial and subcutaneous arterial, venous blood circulation was carried out on areas with maximum manifestations of FA. The skin on the face (cheeks), on the upper and lower extremities (flexural and/ or extensor surfaces), neck, trunk, in places of typical localization of rashes, according to the age of children - all these were examined. The scanograms of pathologically altered skin areas were compared with scanograms of contralateral or adjacent healthy areas of the skin.

All studies were conducted after the informed consent was signed by children and parents. The work followed the ethical principles of the people who act as subjects of the study, taking into account the main provisions of the ICH/GCP (International Conference on Harmonization/Good Clinical Practice) and the Helsinki Declaration of the World Medical Association for Biomedical Research (World Medical Association Declaration Helsinki 1964, 2000, 2008), The Council of Europe Convention on Human Rights and Biomedicine (2007). 
The statistical processing of the research results was carried out using standard algorithms of variation statistics, for calculations the Excel program (Microsoft Office, USA), Statistica 6.0 and the on-line SISA calculator (Simple Interactive Statistical Analysis) were used for calculations, using correlation and parametric analysis. Mean values are given in the form $(M \pm m)$, where $M$ is the mean value of the index, $\mathrm{m}$ is the standard error of the mean, $\mathrm{n}-$ the volume of the analyzed group.

\section{Results}

The distribution of children by age and duration of $\mathrm{H}$. pylori-associated CGD in combination with FA is presented in Table 1.

Clinical symptoms in children with $\mathrm{H}$. pylori-associated CGD in combination with FA were characterized by the presence of leading symptoms: pain $(98.8 \pm 8.9 \%$ of patients), dyspepsia $(91.6 \pm 11.2 \%$ of patients), intoxication (79.1 $\pm 7.2 \%$ of patients) and skin changes (100\%). The analysis of the incidence of inflammation of the mucous membrane of the stomach and duodenum showed the presence of antral gastritis in the sick children: the first degree of activity in 40 patients (23.8\%), II ${ }^{\text {nd }}$ degree - in 100 patients (59.5\%), III ${ }^{\text {rd }}$ degree - in 28 patients $(16.7 \%)$; duodenitis: ${ }^{\text {st }}$ degree of activity in 42 patients $(25.0 \%)$, I $^{\text {nd }}$ degree - in 98 patients (58.3\%), IIIrd degree - in 28 patients (16.7\%).

The severity of skin manifestations of FA in children was evaluated on the scale of SCORAD (Scoring atopic dermatitis, Table 2).

In children aged between 7-10 years, the area of the face was much less frequently affected, and at the same time the rashes were clearly localized, limited periorbitally, periorally; it was a markedly higher frequency of localization of rashes on the upper and lower extremities, especially on the flexural surfaces. Children between11-15 years of age were less likely than younger children to have facial lesions, most often the flexural surfaces of the upper and lower extremities were affected. Typical areas and the incidence of localization of rashes in children of all ages are presented in Table 3.

All the children had a history of itchy skin, the intensity of which is one of the criteria for the severity of the disease. Itching was mild, episodic, it did not affect the sleep, working capacity and general

Table 1. The distribution of children by age and duration of the disease

\begin{tabular}{ccccccc}
\hline & \multicolumn{9}{c}{ Duration of the disease } \\
\cline { 2 - 7 } Age (years) & \multicolumn{2}{c}{ Under a year } & \multicolumn{2}{c}{$1-3$ years } & \multicolumn{2}{c}{ > 3 years } \\
\cline { 2 - 7 } & $a b s$. & 32.5 & 24 & 30 & 30 & 37.5 \\
\hline $7-10$ & 26 & 31.8 & 30 & 34.1 & 30 & 34.1 \\
\hline $11-15$ & 28 & 32.1 & 54 & 32.1 & 60 & 35.7 \\
\hline Total & 54 & & & & & \\
\hline
\end{tabular}

Table 2. Mean values of the SCORAD index depending on the severity of the clinical course of FA in children $(\mathrm{M} \pm \mathrm{m})$

\begin{tabular}{cc}
\hline The severity of the FA clinical course & SCORAD index, points \\
\hline Mild $(\mathrm{n}=50)$ & $18.73 \pm 0.27$ \\
\hline Moderate-severe $(\mathrm{n}=90)$ & $49.87 \pm 1.62$ \\
\hline Severe $(\mathrm{n}=28)$ & $83.59 \pm 2.18$ \\
\hline
\end{tabular}

Table 3. Range and frequency of typical areas of localization of rashes in children of all ages

\begin{tabular}{ccccc}
\hline \multirow{2}{*}{ localization of rashes } & \multicolumn{2}{c}{7 -10-year-old $(n=80)$} & \multicolumn{2}{c}{ 11-15-year-old $(n=88)$} \\
\cline { 2 - 5 } & $n$ & 12.5 & $n$ & $\%$ \\
\hline Face & 10 & - & 3 & 3.4 \\
\hline Hairy part of the head & - & 10.0 & 13 & 14.7 \\
\hline Neck & 8 & 22.5 & 10 & 11.3 \\
\hline Trunk & 18 & 25.0 & 43 & 48.9 \\
\hline Upper limbs & 20 & 22.5 & 16 & - \\
\hline Lower limbs & 18 & 1.25 & - & 3.4 \\
\hline Intertriginous areas, genitals & 1 & 6.2 & 3 & \\
\hline Generalized lesion & 5 & & &
\end{tabular}


condition in $24.2 \%$ of children. Severe persistent itching, which caused the appearance of dehydrating skin, disrupted night sleep, reduced performance was met in $75.8 \%$ of children.

According to ultrasound findings, the mean thickness of skin is likely to be higher than that of healthy children in the control group (Table 4). The thickness of the skin depended on the anatomical area and the age of the children (Table 5).

The children from 7 to 10 years old had a marked thickening of the skin on the upper and lower limbs, to a lesser extent on the face, and in older children a pronounced thickening of the skin on the upper and lower limbs, as well as on the face, was noted $(p<0.05)$. A more detailed description of the skin condition indices in patients and healthy children is presented in Table 6.

The echogenicity of the epidermis was elevated in $73.2 \%$ of cases (the index varied from 113.00 to 197.00 units.) and reduced in $23.2 \%$ (the index varied from 95.00 to 127.00 units.) The echogenicity of the epidermis was unchanged in $3.8 \%$ of the cases (the index ranged from 127.00 to 129.00 units.) The thickness of the epidermis depended on the study area, the patient's age, it was higher compared to the control group, and in children with H. pylori-associated CGD in combination with FA it was $1.06 \pm$
$0.01 \mathrm{~mm}$, the mean echogenicity was $136.87 \pm 1.79$ units. According to the literature, the thickness of the epidermis in healthy children varies from 0.03 to $1.00 \mathrm{~mm}^{13}$. The epidermis was a thickened hyperechoic strip in most children with $\mathrm{H}$. pylori-associated CGD in combination with FA. The boundaries between epidermis and derma in most children with $\mathrm{H}$. pylori-associated CGD in combination with FA were indistinct.

According to the literature, the thickness of the dermis of the unchanged skin varies from 0.50 to $4.00 \mathrm{~mm}^{13}$. In our study, in children with $\mathrm{H}$. pylori-associated CGD in combination with FA, the derma was visualized in the form of strips with increased thickness, decreased echogenicity (the range of variation from 21.00 to 46.00 units.).

The thickness of the dermis depended on the area of study, the age of the patient, was elevated and on average in the group of sick children it was 1.71 $\pm 0.02 \mathrm{~mm}$, the mean echogenicity was $35.7 \pm 0.49$ units, while in the control group children the thickness of the dermis was $44.00 \pm 0.23 \mathrm{~mm}$, the average echogenicity was $44.5 \pm 1.12$ units. The delimitation of the dermis from subcutaneous fat was clear, the outline was uneven in children with $\mathrm{H}$. pylori-associated CGD in combination with FA and in the control group children.

Table 4. The thickness of the skin according to the ultrasound, depending on the localization of rashes in sick children and control group children $(\mathrm{M} \pm \mathrm{m})$

\begin{tabular}{lcc}
\hline \multirow{2}{*}{\begin{tabular}{l} 
Localization \\
\cline { 2 - 3 }
\end{tabular}} & Control group $(n=40)$ & $\begin{array}{c}\text { Thickness of the skin, } m \mathrm{~m} \\
\text { Children from H. pylori-associated CGD in } \\
\text { combination with FA ( } n=168)\end{array}$ \\
\hline Thickness of the skin on the face (cheeks), mm & $1.22 \pm 0.04$ & $2.97 \pm 0.05^{*}$ \\
\hline Thickness of the skin on the upper limbs, $\mathrm{mm}$ & $0.88 \pm 0.02$ & $2.54 \pm 0.03^{*}$ \\
\hline Thickness of the skin on the lower limbs, $\mathrm{mm}$ & $1.15 \pm 0.20$ & $2.73 \pm 0.04^{*}$ \\
\hline
\end{tabular}

Note. ${ }^{*} \mathrm{p}$ - reliability of difference between the figures in sick children and those in the control group $(<0,05)$

Table 5. Skin thickness according to ultrasound findings in children with H. pylori-associated CGD in combination with FA depending on localization of the pathological process, age and in control group children $(\mathrm{M} \pm \mathrm{m})$

\begin{tabular}{|c|c|c|c|c|}
\hline \multirow{3}{*}{ Localization } & \multicolumn{4}{|c|}{ Age group, years } \\
\hline & \multicolumn{2}{|c|}{$\begin{array}{c}\text { Control group } \\
(n=40)\end{array}$} & \multicolumn{2}{|c|}{$\begin{array}{l}\text { Children from } H \text {. pylori-associated CGD } \\
\text { in combination with FA }(n=168)\end{array}$} \\
\hline & $7-10(n=20)$ & $11-15(n=20)$ & $7-10(n=80)$ & $11-15(n=88)$ \\
\hline $\begin{array}{l}\text { Thickness of the skin on the } \\
\text { face (cheeks), mm }\end{array}$ & $1.21 \pm 0.03$ & $1.59 \pm 0.04$ & $2.89 \pm 0.07^{*}$ & $3.59 \pm 0.03^{*}$ \\
\hline $\begin{array}{c}\text { Thickness of the skin on the } \\
\text { upper limbs, mm }\end{array}$ & $0.86 \pm 0.01$ & $1.08 \pm 0.01$ & $2.51 \pm 0.03^{*}$ & $2.91 \pm 0.04^{*}$ \\
\hline $\begin{array}{l}\text { Thickness of the skin on the } \\
\text { lower limbs, mm }\end{array}$ & $1.24 \pm 0.08$ & $1.37 \pm 0.06$ & $2.72 \pm 0.02^{*}$ & $3.24 \pm 0.04^{*}$ \\
\hline
\end{tabular}

Note. ${ }^{*} \mathrm{p}$ - reliability of difference between the figures in sick children and those in the control group $(<0,05)$ 
Table 6. Ultrasound findings for the skin in children with H. pylori-associated CGD in combination with FA and control group

\begin{tabular}{|c|c|c|c|c|}
\hline \multirow{3}{*}{ Finding } & \multicolumn{4}{|c|}{ Incidence } \\
\hline & \multicolumn{2}{|c|}{$\begin{array}{l}\text { Children from } H \text {. pylori-associated } \\
\text { CGD in combination with FA } \\
(n=168)\end{array}$} & \multicolumn{2}{|c|}{$\begin{array}{l}\text { Control group } \\
\qquad(n=40)\end{array}$} \\
\hline & $n$ & $\%$ & $n$ & $\%$ \\
\hline Pronounced thickening of all layers of the skin & 102 & 60.7 & - & - \\
\hline Moderate thickening of all layers of the skin & 66 & 39.3 & - & - \\
\hline The surface of the epidermis is flat & 16 & 9.5 & 40 & 100.00 \\
\hline The surface of the epidermis is uneven & 152 & 90.5 & 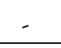 & 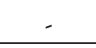 \\
\hline The epidermis is a thin hyperherogenic stripe & 6 & 3.8 & 40 & 100.00 \\
\hline Pronounced thickening of the epidermis & 162 & 96.4 & 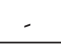 & - \\
\hline The thickness of the epidermis is even & 18 & 10.7 & 40 & 100.00 \\
\hline The thickness of the epidermis is uneven & 150 & 89.3 & 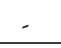 & - \\
\hline The echogenicity of the epidermis is unchanged & 6 & 3.8 & 40 & 100.00 \\
\hline Increased echogenicity of the epidermis & 123 & 73.2 & 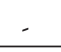 & - \\
\hline Reduced echogenicity of the epidermis & 39 & 23.2 & - & - \\
\hline The structure of the epidermis is homogeneous & 6 & 3.8 & 40 & 100.00 \\
\hline The structure of the epidermis is heterogeneous & 162 & 96.4 & - & - \\
\hline $\begin{array}{l}\text { The boundaries between the epidermis and the dermis are } \\
\text { clear }\end{array}$ & 20 & 11.9 & 40 & 100.00 \\
\hline $\begin{array}{l}\text { The boundaries between the epidermis and the dermis are } \\
\text { indistinct }\end{array}$ & 148 & 88.1 & - & - \\
\hline Hypoechoic strip between epidermis and dermis & 148 & 88.1 & - & - \\
\hline The dermis is a thin strip of reduced echogenicity & 39 & 23.2 & 40 & 100.00 \\
\hline Moderate thickening of the dermis & 47 & 27.9 & 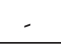 & - \\
\hline Pronounced thickening of the dermis & 121 & 72.1 & - & - \\
\hline The thickness of the dermis is even & 47 & 27.9 & 40 & 100.00 \\
\hline The thickness of the dermis is uneven & 121 & 72.1 & - & - \\
\hline The echogenicity of the dermis is unchanged & 26 & 15.5 & 40 & 100.00 \\
\hline Reduced echogenicity of the dermis & 142 & 84.5 & - & 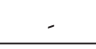 \\
\hline The structure of the dermis is homogeneous & 47 & 27.9 & 40 & 100.00 \\
\hline The structure of the dermis is heterogeneous & 121 & 72.1 & - & - \\
\hline
\end{tabular}

The echogenicity of subcutaneous fat was heterogeneous and ranged from 2.47 to 5.09 units. The average echogenicity was $3.09 \pm 0.04$ units. The thickness of the subcutaneous adipose tissue varied from 2.15 to $20.05 \mathrm{~mm}$ and on average in the group was $12.59 \pm 0.15 \mathrm{~mm}, \mathrm{p}<0.05$.

The findings of the ultrasound examination in the separate layers of the skin were studied in details, evaluated and compared (Table 7).

There was a significant increase in the thickness of the epidermis and dermis in children with H. pylori-associated CGD in combination with FA, compared to the control group. Some other changes were observed regarding the echogenicity of separate layers of the skin. The analysis of the levels of echogenicity in separate layers of the skin (epidermis, dermis), according to ultrasound findings, showed a significant increase in the echogenicity of the epidermis and decreased echogenicity of the dermis in most children with $\mathrm{H}$. pylori-associated CGD in combination with FA, compared to the control group $(\mathrm{p}<0.05)$. The revealed changes can probably be explained by inflammatory infiltration, epidermis condensation, excessive keratitis caused by dryness and edema of the dermis, inflammatory process in the skin in children with FA.

Depending on the course of the disease in children with $\mathrm{H}$-pylori-associated CGD in combination with FA, the following periods are distinguished: acute, subacute and remission periods. The echography in acute period found the pronounced thickening of the skin in these children (epidermis, dermis), 
Table 7. Thickness and echogenicity of the epidermis and dermis according to ultrasonography in children with H. pylori-associated CGD in combination with FA and in the control group

\begin{tabular}{|c|c|c|}
\hline \multirow[b]{2}{*}{ Skin layer } & \multicolumn{2}{|c|}{ Group } \\
\hline & $\begin{array}{c}\text { Control group } \\
(n=40)\end{array}$ & $\begin{array}{c}\text { Children from } H \text {. pylori-associated CGD } \\
\text { in combination with FA }(n=168)\end{array}$ \\
\hline Epidermis & \multicolumn{2}{|c|}{ Thickness, mm } \\
\hline Minimum value & 0.19 & 0.52 \\
\hline Maximum value & 0.61 & 1.74 \\
\hline Mean value & 0.42 & $1.04^{*}$ \\
\hline Statistical deviation & 0.02 & $0.02 *$ \\
\hline Dermis & \multicolumn{2}{|c|}{ Thickness, mm } \\
\hline Minimum value & 0.43 & 1.23 \\
\hline Maximum value & 0.89 & 2.12 \\
\hline Mean value & 0.60 & $1.71^{*}$ \\
\hline Statistical deviation & 0.02 & $0.02 *$ \\
\hline Epidermis & \multicolumn{2}{|c|}{ Echogenicity, units } \\
\hline Minimum value & 125.89 & 94.78 \\
\hline Maximum value & 129.34 & 189.56 \\
\hline Mean value & 125.77 & $136.13^{*}$ \\
\hline Statistical deviation & 0.13 & $1.78^{*}$ \\
\hline Dermis & \multicolumn{2}{|c|}{ Echogenicity, units } \\
\hline Minimum value & 42.00 & 21.66 \\
\hline Maximum value & 45.67 & 45.50 \\
\hline Mean value & 44.00 & $35.76^{*}$ \\
\hline Statistical deviation & 0.28 & $0.47^{*}$ \\
\hline
\end{tabular}

Note. ${ }^{*} \mathrm{p}$ - reliability of difference between the values in children with H. pylori-associated CGD in combination with FA and in those from the control group $(\mathrm{p}<0,05)$.

especially of the derma, violation of clearness of the skin layers, increased echogenicity of the epidermis, diffuse reduction of echogenicity of the dermis and heterogeneity of its structure, the appearance of a characteristic hypoechoic strip between epidermis and dermis, which can serve as a marker of the activity of the inflammatory process. The boundary between the dermis and the subcutaneous fat layer was less pronounced than that in healthy children. There was often an irregularity in the surface of the epidermis. The Doppler examination found an increased intradermal arterial and venous, subcutaneous arterial and venous blood flow (Table 8).

In the subacute period, the overall thickness of the skin, as well as its individual layers (epidermis, dermis), reliably decreased in comparison with the acute period, the echogenicity of the dermis increased as well, therefore the intermediate hypoechoic strip between the epidermis and the dermis could not be visualized, but the ultrasound characteristics of the epidermis remained the same. The revealed dynamics in the echogenicity of the layers of the skin reduced

Table 8. Features of intradermal and subcutaneous arterial and venous blood flow according to ultrasound findings in different periods of the disease in children with H. pylori-associated CGD in combination with FA

\begin{tabular}{|c|c|c|c|c|c|c|}
\hline \multirow{4}{*}{ Blood flow } & \multicolumn{6}{|c|}{ Frequency of detecting an increased blood flow $(n=168)$} \\
\hline & \multicolumn{6}{|c|}{ Period of the disease } \\
\hline & \multicolumn{2}{|c|}{ Acute } & \multicolumn{2}{|c|}{ Subacute } & \multicolumn{2}{|c|}{ Remission } \\
\hline & N & $\%$ & $n$ & $\%$ & $n$ & $\%$ \\
\hline Intradermal arterial & 90 & 53.5 & 40 & 23.8 & 38 & 22.6 \\
\hline intradermal venous & 12 & 7.1 & 7 & 4.2 & 5 & 2.9 \\
\hline subcutaneous arterial & 112 & 66.6 & 13 & 7.7 & 10 & 5.9 \\
\hline subcutaneous venous & 100 & 59.5 & 40 & 23.8 & 38 & 22.6 \\
\hline
\end{tabular}


the clarity of their differentiation both in acute and subacute periods. Doppler examination could find an increased intradermal arterial and venous blood flow much less frequent, however an increased subcutaneous arterial and venous blood flow was recorded.

In the remission period, the ultrasound pattern of the skin practically corresponded to that of the control group, there were no significant differences, its thickness approached the normal, but it remained higher compared to the skin of healthy children. Doppler ultrasonography recorded blood circulation both in the skin and in the subcutaneous layer in the remission period in a small part of the children, which practically corresponded to the results obtained in healthy children.

According to the literature, nonlesional skin differs significantly from lesional skin in atopic dermatitis and from skin of healthy subjects ${ }^{15,31-33}$. Noninvasive methods are able to measure subclinical skin disturbances within normal-appearing skin, which are not evaluated using standard clinical scores. They are objective and may facilitate communication between different research groups. Atopic dermatitis is one of the inflammatory diseases and typical sonographic features of this dermatosis are the presence of a hypoechoic band and a decrease in the average skin echogenicity. According to the literature, a hypoechoic band is also known as a subepidermal low echogenic band (SLEB) and expresses infiltration of inflammatory cells and papillary edema ${ }^{27-29}$. The reduction of this band may serve as a marker of the efficacy of received therapy, but on the other hand the lack of its complete decrease may indicate the need for further continuation of treatment. Analyzing the ultrasound of uninvolved AD skin, authors noted the presence of SLEB in 7 patients (12.7\%). Its average thickness was 0.140 $\pm 0.05 \mathrm{~mm}$, lower compared to the average thickness of SLEB observed in skin lesions. Currently, there are no literature data to explain this phenomenon. We think that this band may suggest the existence of subclinical (and therefore imperceptible to the naked eye) inflammation, which may lead in the future to the development of fully symptomatic skin lesions. increased echogenicity, like decreased SLEB, may indicate a regression of inflammation and reduction of edema/infiltration in the upper layers of the dermis. Danish researchers reported the presence of a wide SLEB in eczematous skin compared with uninvolved skin and, what is more, about the SLEB in the skin of healthy controls ${ }^{27}$.

Therefore, the severity of ultrasound changes in the skin in children with $\mathrm{H}$. pylori-associated CGD in combination with FA was determined by age, localization of the process and period of the disease.
Using the skin ultrasound does not require special preparation of the patient, it does not have any contraindications. The main directions of using ultrasound of the skin are studying the skin morphology, measuring thickness and acoustic density of the epidermis and dermis with specification of their boundaries. Comparing the clinical picture and the results of the skin ultrasound increases the reliability of the findings obtained during the examination.

\section{Conclusions}

Ultrasound skin examination is a highly informative diagnostic method in children. The echographic picture of normal skin is characterized by a clear differentiation of the skin layers, differing in thickness and echogenicity. The ultrasound structure of the skin in children with $\mathrm{H}$. pylori-associated CGD in combination with FA is characterized by a pronounced thickening of all its layers, the presence of a hypoechoic strip in the superficial layer of the dermis and the strengthening of intradermal arterial and subcutaneous arterial and venous blood flow. The subacute period of atopic dermatitis is characterized by a decrease in the thickness of the skin layers, the disappearance of the hypoechoic strip in the superficial layer of the dermis, the absence of intradermal arterial and strengthening of the intradermal and subcutaneous venous blood flow, the attenuation of subcutaneous arterial blood flow compared with the period of exacerbation. During the remission, thickening of the layers of the skin and disturbance of their differentiation, absence of visible intradermal and subcutaneous blood flow persist.

\section{Compliance with Ethics Requirements:}

"The authors declare no conflict of interest regarding this article"

"The authors declare that all the procedures and experiments of this study respect the ethical standards in the Helsinki Declaration of 1975, as revised in 2008(5), as well as the national law. Informed consent was obtained from all the patients included in the study"

„No funding for this study"

\section{References}

1. Gary S, Helyeh S, David L. Advances in the management of food allergy in children. Curr Pediatr Rev. 2018; 8:14.

2. Maciorkowska E, Panasiuk A, Kaczmarsk M. Concentrations of gastric mucosal cytokines in children with food allergy and Helicobacter pylori infection. World J Gastroenterol. 2005; 21;11(43):6751-6 
3. Ingle SB, Hinge Ingle CR. Eosinophilic gastroenteritis: an unusual type of gastroenteritis. World J Gastroenterol 2013; 19: 5061-6.

4. Palanduz A, Erdem L, Cetin BD, Ozcan NG. Helicobacter pylori infection in family members of patients with gastroduodenal symptoms. A cross-sectional analytical study. Sao Paulo Med J. 2018 Jun 4:0. (Epub ahead of print)

5. Kalach N, Bontems P, Raymond J. Helicobacter pylori infection in children. Helicobacter. 2017; 22 (1): e12414.

6. Saghier S, Schwarz SM, Anderson V, et al. Pediatric Helicobacter pylori gastropathy demonstrates a unique pattern of gastric foveolar hyperplasia. Helicobacter. 2018; 23(3):e12487.

7. Akbulut UE, Fidan S, Emeksiz HC, Ors OP. Duodenal pathologies in children: a single-center experience. J Pediatr (Rio J). 2018; 94(3):273-278.

8. Blanchard TG, Czinn SJ. Identification of Helicobacter pylori and the evolution of an efficacious childhood vaccine to protect against gastritis and peptic ulcer disease. Pediatr Res. 2017;81(1-2):170-176.

9. Kotilea K, Kalach N, Homan M, Bontems P. Helicobacter pylori Infection in Pediatric Patients: Update on Diagnosis and Eradication Strategies. Paediatr Drugs. 2018; 22:1-15.

10. Alarcon T, Jose Martinez-Gomez M, Urruzuno P. Helicobacter pylori in pediatrics. Helicobacter. 2013; 18(1):52-7.

11. Chey WD, Wong BC. American College of Gastroenterology guideline on the management of Helicobacter pylori infection. Am J Gastroenterol. 2007; 102:808-1825.

12. Correa Silva RG, Machado NC, Carvalho MA, Rodrigues MA. Helicobacter pylori infection is high in paediatric nonulcer dyspepsia but not associated with specific gastrointestinal symptoms. Acta Paediatr. 2016;105(5):e228-31.

13. Broide E, Richter V, Mendlovic S, et al. Lymphoid follicles in children with Helicobacter pylori-negative gastritis. Clin Exp Gastroenterol. 2017; 11; 10:195-201.

14. Razavi A, Bagheri N, Azadegan-Dehkordi F, et al. Comparative immune response in children and adults with H. pylori infection. J Immunol Res. 2015; 2015:315957.

15. Dror G, Muhsen K. Helicobacter pylori infection and chil dren's growth: an overview. J Pediatr Gastroenterol Nutr. 2016; 62(6):e48-59.

16. Daugule I, Karklina D, Rudzite D, et al. Prevalence of Helicobacter pylori infection among preschool children in Latvia: no significant decrease in prevalence during a ten year period. Scand J Public Health. 2016; 44(4):418-22.

17. Alper A, Hardee S, Rojas-Velasquez D, et al. Prevalence and clinical, endoscopic, and pathological features of duodenitis in children. J Pediatr Gastroenterol Nutr. 2016; 62(2):314-6.

18. Kolho KL, Haapaniemi A, Haahtela T, Rautelin H. Helicobacter pylori and specific immunoglobulin
E antibodies to food allergens in children. J Pediatr Gastroenterol Nutr. 2005; 40(2):1.

19. Shiotani A, Miyanishi T, Kamada T, Haruma K. Helicobacter pylori infection and allergic diseases: epidemiological study in Japanese university students. J Gastroenterol Hepatol. 2008; 23(7 Pt 2):e29-33.

20. Lazebnik LB, Chernutskaia SP, Gervazieva VB, Sukhareva GV. H. pylori in development of allergic diseases in patients with gastroduodenal diseases. Ter Arkh. 2008; 80(12):63-6.

21. Krina F. Food allergy and Helicobacter pylori infection. $J$ Gastroenterol. 2018; 31(3):186-91.

22. Bergmann MM, Caubet JC, Boguniewicz M, Eigenmann PA. Evaluation of food allergy in patients with atopic dermatitis. J Allergy Clin Immunol Pract. 2013;1(1):22-8.

23. Dańczak-Pazdrowska A, Polańska A, Silny W, et al. Seemingly healthy skin in atopic dermatitis: observations with the use of high-frequency ultrasonography, preliminary study. Skin Res Technol. 2012; 18:162-7.

24. Polańska A, Dańczak-Pazdrowska A, Silny W, et al. Nonlesional skin in atopic dermatitis is seemingly healthy skin - observations using noninvasive methods. Wideochir Inne Tech Maloinwazyjne. 2013; 8(3): 192-199.

25. Zubeyko KA, Kurlovich MV, Smyslenova MV, Privalova EG. Ultrasonography of the Skin (Literature Review). Radyolohyia - Praktyka 2014; No 6 (48):40-49.

26. Mandava A, Ravuri PR, Konathan R. High-resolution ultrasound imaging of cutaneous lesions. Indian J Radiol Imaging. 2013; 23(3):93-102.

27. Jasaitiene D, Valiukeviciene S, Linkeviciute $G$, et al. Principles of high-frequency ultrasonography for investigation of skin pathology. J Eur Acad Dermatol Venereol. 2011; 25:375-82.

28. Polańska A, Dańczak-Pazdrowska A, Silny W, et al. High-frequency ultrasonography in monitoring the effects of treatment of selected dermatoses. Postep Derm Alergol. 2011; 28:255-60.

29. Jemec GB, Gniadecka M, Ulrich J. Ultrasound in dermatology. Part I. High frequency ultrasound. Eur J Dermatol. 2000; 10:492-7.

30. Order of MOH Ukraine of 29.01.2013 № 59. Unified clinical protocols of medical care for children with diseases of the digestive system (Regulations Ministry of Health of Ukraine).

31. Turnbull JL, Adams HN, Gorard DA. Review article: the diagnosis and management of food allergy and food intolerances. Aliment Pharmacol Ther. 2015; 41(1):3-25.

32. Perry TT, Pesek RD. Clinical manifestations of food allergy. Pediatr Ann 2013; 42: 96-101.

33. Mansouri M1, Rafiee E, Darougar S, Mesdaghi $\mathrm{M}$, Chavoshzadeh Z. Is the atopy patch test reliable in the evaluation of food allergy-related atopic dermatitis? Int Arch Allergy Immunol. 2018; 175(1-2):85-90. 